\title{
Kas-iskelet sistemi hastalıklarında proloterapi
}

\section{Prolotherapy in musculoskeletal system diseases}

\author{
Selami Çakmak
}

Acıbadem Kadıköy Hastanesi, Ortopedi ve Travmatoloji Kliniği, İstanbul

\begin{abstract}
Ekleme ait ve omurga veya tendon kaynaklı ağrı, oldukça yaygın olarak karşılaşılan kas-iskelet sistemi sorunlarındandır. Tedaviye yönelik yardımcı yöntemler arasında yer alan, eklem içi veya eklem çevresine uygulanan bir tedavi yöntemi olan proloterapi, son yıllarda oldukça popülarite kazanmıştır. Ağrıyı gidermeye yönelik ve fonksiyonel kapasiteyi arttırıcı etkisi olduğu öne sürülen proloterapi yönteminde, hipertonik dekstroz gibi proliferan veya sklerozan solüsyonlar kullanılır. Özellikle tendon-kemik bileşkesi veya bağ-kemik bağlantı noktalarına yapılan enjeksiyonlar ile, vücudun iyileştirme yolaklarının aktif hale getirilmesi ve inflamasyonun tetiklenmesi amaçlanır. Bu konuda eğitim almış uzman kişilerin uyguladığı proloterapi tekniği ile, tedavinin ağrının azaltılmasında ve fonksiyonel sonucu iyileştirmede etkin olduğunu bildiren çalışmalar mevcuttur. Her ne kadar henüz proloterapinin klinik sonuçlar üzerine etkili olduğunu gösteren "Level 1" düzeyde bir çalışma mevcut değilse de, yapılan çalışmaların öncü olma özelliği bulunmaktadır.
\end{abstract}

Anahtar sözcükler: proloterapi; tendinopati; eklem ağrısı; diz ağrısı

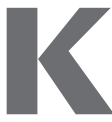
as-iskelet sistemi ile ilgili rahatsızlıklar ve yaralanmalardan kaynaklanan ağrının tedavisinde, eklem içi ve yumuşak doku enjeksiyonları oldukça yaygın uygulanan yardımcı tedavi yöntemleridir. Ağrının kesilmesinde enjeksiyon tedavisinin alternatifi ağızdan alınan ağrı kesiciler ve steroid olmayan anti-inflamatuvar ilaçlardır ki, bu ilaç tedavilerinin uzun süreli olması halinde ciddi yan etkiler söz konusudur. ${ }^{[1]}$ Bir ilacın veya solüsyonun lokal olarak bir anatomik bölgeye uygulanması ile, o ilaca ait sistemik etki veya yan etkilerden kaçınılmış olur. Ancak, enjeksiyon tedavilerinin başarıya ulaşmasındaki en önemli hususlardan birisi, anatomik bölgelerin iyi bilinmesi ve yumuşak doku ile kemiksel rehber noktaların uygun şekilde belirlenmesidir.
Pain originating from joint problems, and spinal or tendon disorders is one of the commonly seen musculoskeletal problems. Prolotherapy, which is a supportive treatment and applied intraarticularly, has gained popularity in recent years. Proliferative or sclerosing solutions, such as hypertonic dextrose, are used in the prolotherapy method which is suggested to have a pain relief effect and enhance functional capacity. Injections made specifically to tendon-bone junctions or ligament-bone attachment sites are intended to activate the body's healing pathways and trigger inflammation. There are studies reporting that the prolotherapy technique applied by trained specialists is effective in reducing the pain and in improving the functional outcome. Although there is no "Level 1" study yet to show that prolotherapy is effective on clinical outcomes, reports of recent studies have value as pioneering works.

Key words: prolotherapy; tendinopathy; joint pain; knee pain

Eklem içine veya yumuşak dokulara uygulanacak enjeksiyon yöntemlerinin, hem tanıda hem de tedavide yeri vardır. Tedavi için, ağrıyı ve inflamasyonu azaltmak amacıyla lokal anestezik, steroid uygulanabilir. Aynı zamanda, iyileşmenin hızlandırılması ve desteklenmesi amacıyla da proloterapi gibi kişinin bağışıklık sistemini-inflamasyonu uyarıcı enjeksiyon tedavileri de yapılabilir. ${ }^{[2]}$

Proloterapi, kronik kas iskelet sistemi ağrılarının tedavisinde kullanılmaktadır. "Prolo" kelimesi de "proliferasyon" fonksiyonunun vurgulanması amacıyla seçilmiştir. Hedeflenen, büyüme ve yeniden oluşumdur. Proloterapi uygulamasının özünde yatan prensip, kişinin kendi inflamatuvar cevabını harekete geçirerek,

- İletişim adresi: Doç. Dr. Selami Çakmak, Ömerpaşa Sokak No: 98 Daire: 25 Marmara Apt. Erenköy, Kadıköy, İstanbul Tel: 0505 - 7745830 e-posta: selamicakmak@gmail.com

- Geliș tarihi: 20 Mart 2017 Kabul tarihi: 20 Mart 2017 
hasarlanan alanda yer alan (bağ, tendon vb.) sağlıklı olmayan hücre ve dokuların uzaklaştırılması; yeni, sağIıklı bir doku oluşturulmasıdır. Özetle; bu süreç, hasarlı ve zayıf bir doku bölgesinin yeni doku oluşumu ile güçlendirilmesi olarak da ifade edilebilir. Özellikle tendinopatilerde kullanımı yaygınlaşmış olan proloterapinin, hasarlanmış dokuda etkin bir tedavi yöntemi olduğu gösterilmiştir.

ilk defa 1930'lu yıllarda, bir genel cerrah olan Dr. George Stuart Hackett tarafindan "skleroterapi” adıyla uygulanmakta olan proloterapi tedavi yönteminin uygulanma mantığının keşif öyküsünde, rastgele bir keşif yer alır. ${ }^{[3]}$ Dr. Hackett, fitık ameliyatlarında kullandığı bazı sklerozan maddelerin yanlışlıkla kemiktendon bileşke noktalarına enjekte edilmesi ile, bu alanlarda "doku proliferasyonu" olduğunu gözlemlemiştir. Oluşan bu yeni doku proliferasyonuna atfen de "proloterapi" adlandırılması yapılmıştır.

Proloterapi, yenileyici ve tamamlayıcı yardımcı tedavi yöntemlerinden birisidir. Aslında proloterapi bir enjeksiyon tekniğinin adıdır. Bu teknik ile, proliferan maddeler kas-iskelet sisteminde istenilen anatomik bölgelerde oluşturulacak mikrotravmalar ile uygulanır. Proloterapi tedavi tekniği ile, farklı proliferan maddeler veya hücreler uygulanabilir: hipertonik dekstroz, mannitol, sodyum morhuat, trombositten zengin plazma, kök hücre, ozon vb. ${ }^{[4,5]}$ Sonuç olarak; proloterapi, kas iskelet sisteminin akut veya kronik ağrılarında, eklem ve bağ yaralanmaları ile gevşekliklerinde eklem içine veya eklem çevresindeki bağ-tendonların kemik bileşke noktalarına, eklem stabilitesinin arttırılması amacıyla çeşitli maddelerin ve/veya hücrelerin (proliferatif, sklerozan, irritan, rejeneratif vb.) enjekte edildiği bir enjeksiyon tekniğinin adıdır. ${ }^{[6]}$

Bir bağda meydana gelen hasar veya bir tendonda kronik bir yüklenme sonrası meydan gelen yıpranma sonucunda, eklemde stabilite kaybı oluşacağı ve bunun sonucu olarak da eklem kıkırdağında bozulmalar ile osteoartrit gelişeceği öne sürülmektedir. Eklemdeki kıkırdak dejenerasyonu ile, ağrı oluşur ve kişinin eklem hareket kabiliyeti de azalır. Azalan hareketin çevre kaslarda atrofiye neden olması ile, diz çevresi bağlarda daha da fazla gevşeklik oluşacağı düşünülmektedir. Vücudumuzda oluşan bu yaralanmalar sonucunda fizyolojik bir inflamasyon cevabı başlar. Bu cevap, birbirini takip eden ve zamansal olarak iç içe geçmiş bir iyileşme yolağıdır. İşte, proloterapi tekniği ile amaçlanan bu iyileşme, yolağının tetiklenmesi ile fizyolojik inflamasyon cevabının başlatılmasıdır.

Yapılan enjeksiyon ile, hem iğnenin mekanik olarak oluşturduğu mikro-travma etkisinden yararlanılmakta hem de ortama enjekte edilen hipertonik dekstroz solüsyonunun oluşturacağı ozmotik etki ile hücresel düzeyde inflamatuvar süreç tetiklenmektedir. ${ }^{[7]}$ Kişinin problem yaşadığı anatomik bölgeler ve eklemlerin çevresine yapılan bu uyarılar ile oluşturulan iyatrojenik mikro-hasarlandırma, adeta vücutta iyileşme için bir hedef belirleme işlemidir. Vücutta bu bölgelerde lokal büyüme faktörlerinin salınımı arttırılırken, aynı zamanda kemotaktik hücrelerin çağrılması ile inflamatuvar süreç desteklenir. Lokal fibroblast uyarılması, bağ veya tendonların rejenerasyonuna katkı sağlar; yeni kollajen fibriller oluşur. Yani, proloterapi etkisiyle oluşturulan inflamatuvar cevabın, doğal fizyolojik bir yara iyileşmesi esnasında oluşan inflamatuvar cevaptan bir farkı yoktur. İyileşme süreci neticesinde bağ ve tendonların güçlenmesi, eklemin de stabil olmasına neden olacak, stabil eklemde hasarlanma süreci duraklayacak ve ağrı da ortadan kalkacaktır. Özetle; proloterapi ile elde edilen cevabın, anlatılan mekanizmalar ve yolaklarla gerçekleştiği düşünülmektedir.

\section{KULLANILAN MADDELER}

Kullanılan proliferatif maddeler arasında en güvenilir olanı ve bu nedenle de en yaygın kullanılanı, hipertonik dekstroz solüsyonudur. ${ }^{[7]}$ Hazırlanan solüsyonlarda dekstroz yoğunluğu, eklem içi uygulamalarda \%25, bağ-kemik bileşke noktalarında ise \%15'tir. Yapılan çalışmalarda dekstrozun yoğunluğu etkisinin, \%10'un altında ise rejeneratif, üstünde ise proliferatif olduğu gösterilmiştir. Düşük yoğunluktaki dekstrozun hücresel seviyede nörojenik yolaklarla ağrı kesici etkisinin olduğu, yüksek yoğunluktaki dekstrozun ise ozmotik etki ile proliferasyonu arttırdığı öne sürülmektedir. ${ }^{[8]}$ Ülkemizde \%5, \%10, $\% 20, \% 30$ ve $\% 50$ yoğunlukta dekstroz solüsyonları vardır. Uygulanacak solüsyonlar, dekstroz, serum fizyolojik ve en son olarak lidokain ile belli oranlarda birleştirilerek hazırlanır. Proloterapide kullanılan diğer solüsyonlar ise çoğunlukla proliferan özellikleri olan fenol, gliserin, trombosit, ozon, kök hücre, çinko sülfattır.

\section{UYGULANMASI}

Proloterapi uygulanması, öncelikle fizik muayenenin ayrıntılandırılması ile başlar. Fizik muayenenin ana unsurlarından olan palpasyon, anatomik enjeksiyon noktalarının doğru olarak saptanması ve güvenli bir enjeksiyon için şarttır. Uygulama noktalarının belirlenmesinde, her zaman ulaşılabilir olmasa da ultrasonografi oldukça yararlıdır. Proloterapinin uygulanacağı noktalar, bağ ve tendonların kemiğe yapışma 
noktalarıdır. Bu noktalarda, dokunun damarlanması, yani beslenmesi göreceli olarak zayıftır. Bu noktaların hedef alınması ve desteklenmesinin nedeni budur. Yukarıda anlatılan iyileşme süreci ve inflamasyon basamakları göz önüne alındığında, enjeksiyon seanslarının üç-dört hafta aralıklarla yapılmasının uygun olduğu kabul edilmektedir.

ilk birkaç seans proloterapi enjeksiyonu sonrasında, hastanın klinik tablosunda semptomlarında iyileşme olması beklenir. Bu dönemdeki iyilik hali ile, eklem yaralanma öncesindeki gibi tam yük vermeye izin verilebilir hale gelir. Ancak, iyileşme süreci tamamlanmadığı için dayanma gücü tam olmayan bağ ve tendonlar yeniden yaralanabilir. Bunun nedeni, yeni oluşacak kollajenin yeniden organize olması ve bağ dokusunun eski gücüne kavuşması için 6 ay ila 1 yıl kadar sürenin geçmesi gereğidir.

Enjeksiyon esnasında ve sonrasında oluşabilecek komplikasyonlardan kaçınmak için; antisepsi kurallarına dikkat edilmeli, anatomik noktalar doğru belirlenmeli, iğne ucu ile kemik teması sağlandıktan sonra uç 1-2 mm yüzeye doğru çekilerek enjeksiyon yapılmalı ve iğne ucunun damar veya sinir ile temasta olduğu düşünülüyorsa enjeksiyondan vazgeçilmelidir. Enjeksiyonlar, uygulama yapılan bölgeye çok sayıda ve her defasında küçük enjeksiyonlar şeklinde yapılmalıdır. Ağrılı noktalara yapılan enjeksiyonlarda erken cevap beklenirken, fonksiyonlardaki düzelme ilerleyen seanslarda kendini gösterir. Kişinin yaşına, sorunun süresine (akut/kronik) ve genel sağlık durumuna bağlı olarak, 3-4 ila 8-10 arasında tedavi seansı gerekebilir. Tedavi seansları arası, değerlendirme sonucuna ve semptomlarda düzelmenin olup olmamasına göre değişebilir; tedavi planı yeniden şekillendirilebilir. Diz çevresinde proloterapi uygulamasına yönelik örnek Şekil 1'de görülmektedir.

Proloterapinin temel felsefesinde inflamasyon olduğundan, terapi seansları öncesi, esnası ve en az iki hafta sonrasında, steroidler ve steroid olmayan antiinflamatuvar ilaçların kullanılmaması gerekir.

\section{ENDIKASYONLARI}

Proloterapinin kas iskelet sistemi hastalıkları ile ilgili tedavideki rolünü araştıran çeşitli çalışmalar bulunmaktadır. Bu çalışmaların çoğunda, tendon sorunları, kronik bel ağrısı ve eklem ağrıları ele alınmıştır. ${ }^{[9-11]}$

Proloterapinin osteoartrit üzerindeki etkisinin araştırıldığı bir çalışma sonucunda, hipertonik dekstroz solüsyonunun eklem içinde hiperozmolar bir ortam oluşturarak hücrelerden platelet-derive büyüme faktörlerinin salınımına neden olduğu bildirilmiştir. Böylelikle de, eklemdeki dejenerasyon sürecinin yavaşlatıldığı öne sürülmektedir.[12] Diğer bir sistematik bir inceleme ve meta-analiz çalışmasında da, proloterapinin osteoartritik ağrının azaltılmasında egzersiz, lokal anestezikler ve steroid enjeksiyonlarından daha iyi sonuç verdiği bildirilmektedir. ${ }^{[13]} \mathrm{Her}$ ne kadar kanıta dayalı, uzun takipli ve randomize "Level 1" çalışmalar henüz olmasa da, mevcut çalışmaların, öncü nitelik taşıması ve ileride yapılacak çalışmalarda karşılaştırma amaçlı kullanılmasına olanak vermesi açısından önemi büyüktür.

Aşil tendinopatilerinde proloterapinin güvenli ve etkin bir tedavi şekli olduğu söylense de, bu çalışmalarda yer alan hasta sayısının az olması ve çalışmaların kanıta dayalı seviyesinin düşük olması nedeniyle, sonuçların genel kabul görür olması mümkün değildir. ${ }^{[14,15]}$

\section{KONTRENDIKASYONLAR}

- Enjeksiyon yapılması planlanan anatomik bölgede selülit, enfekte bursa veya açık yarası olanlar.

- Kontrol altında olmayan antikoagülan tedavi alanlar.

- Ciddi koagülopati sorunu olanlar.

- Eklem protezi olanlar.

- Proloterapide kullanılan maddelere karşı alerjisi olanlar.

- Rölatif olarak ise;

- Hamilelik.

- Daha önceki 2-3 enjeksiyona cevap alınamayanlar.

- Özellikle yük taşıyan eklemlere üçten fazla enjeksiyon yapılanlar.

\section{SONUÇ}

Proloterapi tekniği ile, vücudun iyileştirme mekanizması olan inflamasyonun tetiklenmesi amaçlanır. Ağrı yolakları üzerine erken dönemdeki etkisi ile ağrı azaltılır; orta ve uzun dönemdeki etkisi ile de bağ-tendon güçlenmesi ile eklemde stabilite sağlanmış olur. Lokal olarak stabilitenin sağlanması, vücudun genelinde var olduğu düşünülen ve hasarlanma ile kaybolan bağ gerilim ve dengesinin yeniden teşkil edilmesini de sağlar. Ancak, uygulamadaki birçok parametreyi (solüsyonun hazırlanış şekli, proliferan maddenin kendisi ve yoğunluğu, endikasyonları, uygulama lokalizasyonları, uygulama zamanı ve sıklığı, optimal takip süresi vb.) içeren farklılıklar, kanıta dayalı verilerin elde edilmesine olanak vermemektedir. 


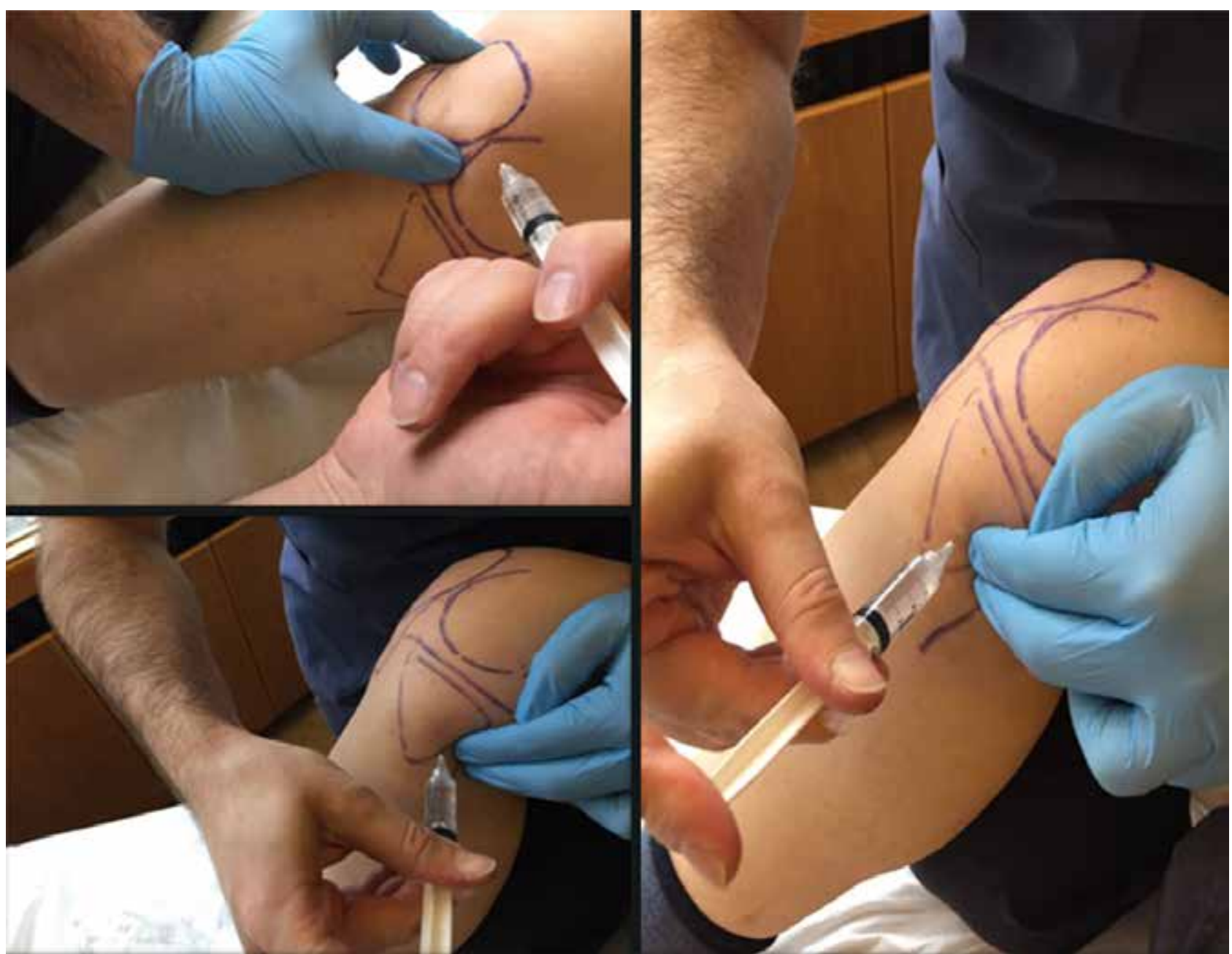

Şekil 1. Diz çevresine yapılan proloterapi enjeksiyonlarında enjeksiyon noktalarının doğru bir şekilde belirlenmesi amacıyla cilt üzerinde anatomik izdüşümlerin çizilmesi oldukça yararlıdır.

\section{KAYNAKLAR}

1. Ayhan $\mathrm{E}$, Kesmezacar $\mathrm{H}$, Akgun I. Intraarticular injections (corticosteroid, hyaluronic acid, platelet rich plasma) for the knee osteoarthritis. World J Orthop 2014;5(3):351-61. Crossref

2. Barkdull, TJ, O'Connor, FG, McShane, JM. Joint and soft tissue aspiration and injection (arthrocentesis). In: Pfenninger, JL, Fowler, GC, editors. Procedures for Primary Care, 3rd ed. Philadelphia: Elsevier, Mosby; 2011. p.1303-21.

3. Hackett GS, Hemwall GA, Montgomery GA. Ligament and tendon relaxation treated by prolotherapy, 5th ed. Gustav A. Hemwall, Oak Park (IL); 1993.

4. KimWJ, Shin HY, KooGH, ParkHG, HaYC, ParkYH. Ultrasoundguided Prolotherapy with Polydeoxyribonucleotide Sodium in Ischiofemoral Impingement Syndrome. Pain Pract 2014;14(7):649-55. Crossref
5. Rabago D, Lee KS, Ryan M, Chourasia AO, Sesto ME, Zgierska A, Kijowski R, Grettie J, Wilson J, Miller D. Hypertonic dextrose and morrhuate sodium injections (prolotherapy) for lateral epicondylosis (tennis elbow): results of a singleblind, pilot-level, randomized controlled trial. Am J Phys Med Rehabil 2013;92(7):587-96. Crossref

6. Akçacıoğlu M, Akçacıoğlu S, Cesur N, Çifçi ÖT. Temel Proloterapi El Kitabı, 1. baskı. Akademisyen Yayınevi; 2015.

7. Rabago D, Slattengren A, Zgierska A. Prolotherapy in primary care practice. Prim Care 2010;37(1):65-80. Crossref

8. Hauser RA, Hauser MA, Baird NM. Evidence-based use of dextrose prolotherapy for musculoskeletal pain: a scientific literature review. J Prolotherapy 2011;3(4):765-89.

9. Bertrand $H$, Reeves $K D$, Bennett $C J$, Bicknell $S$, Cheng AL. Dextrose Prolotherapy Versus Control Injections in Painful Rotator Cuff Tendinopathy. Arch Phys Med Rehabil 2016;97(1):17-25. Crossref 
10. Yelland MJ, Glasziou PP, Bogduk N, Schluter PJ, McKernon M. Prolotherapy injections, saline injections, and exercises for chronic low-back pain: a randomized trial. Spine (Phila Pa 1976) 2004;29(1):9-16. Crossref

11. Rabago D, Best TM, Beamsley M, Patterson J. A systematic review of prolotherapy for chronic musculoskeletal pain. Clin J Sport Med 2005;15(5):376-80.

12. Rabago D, Best TM, Zgierska AE, Zeisig E, Ryan M, Crane D. A systematic review of four injection therapies for lateral epicondylosis: prolotherapy, polidocanol, whole blood and platelet-rich plasma. Br J Sports Med 2009;43(7):471-81. Crossref
13. Hung CY, Hsiao MY, Chang KV, Han DS, Wang TG. Comparative effectiveness of dextrose prolotherapy versus control injections and exercise in the management of osteoarthritis pain: a systematic review and meta-analysis. J Pain Res 2016;9:847-57. Crossref

14. Lyftogt J. Prolotherapy and Achilles tendinopathy: a prospective pilot study of an old treatment. Australasian Musculoskeletal Medicine 2005;10:16-9.

15. Yellend M, Sweeting K, Lyftogt J, Ng SK, Scuffham PA, Evans KA. Prolotherapy injections and eccentric loading exercises for painful Achilles tendinosis: a randomized trial. Br J Sports Med 2011;45(5):421-8. Crossref 